\title{
Entrevista com Guacira Louro
}

\section{Por Fernando Seffner}

Fernando Seffner (F.S.): Embora exista o currículo Lattes, eu vejo que as pessoas perguntam muito sobre o teu histórico e sobre essa tua aproximação com o gênero e elas fazem referência ao "Corpo Educado", em geral eu indico este artigo, entre outras coisas, quando a pessoa quer saber mais sobre isso, pois nele fazes reminiscências a tua vida escolar. Isso porque as pessoas ficam curiosas sobre o motivo pelo qual te atraístes por esse assunto. Então a gente podia comentar sobre isso. Não são necessárias datas, instituições, isso está bem claro e completo no teu Lattes ${ }^{1}$, então a gente pode ter essas informações lá, inclusive sobre os prêmios recebidos. Mas eu considero que seria interessante te escutar e eu estou lembrando um pouco do Corpo Educado, aonde ao fazer algumas reminiscências, digamos assim, tem um pouco de memória, um pouco de gênero e educação, não é?

Guacira Louro (G.L.): Não, é assim, até que a minha vida escolar e acadêmica não é muito acidentada, ao contrário, eu estudei a vida toda no Instituto de Educação, entrei com 5 anos e saí com 19 como professora normalista. Então eu tinha feito escola normal em uma instituição marcadamente feminina e, depois, como eu costumo dizer, eu só atravessei a rua e fiz vestibular para História, do outro lado da rua. Então minha trajetória é essa, fui normalista, depois fiz o curso de História e pouco tempo depois fui fazer mestrado em Educação e fiz concurso na UFRGS para professora de História da Educação. Eu entrei no Departamento de Estudos Básicos na História da Educação, nessa disciplina que é - era pelo menos - uma disciplina de $1^{\circ}$ semestre num curso de Pedagogia, numa época em que podia se dizer que não haviam rapazes no curso de Pedagogia, era uma disciplina exclusivamente para garotas, meninas.

F.S.: Hoje em dia tem 5\%.

G.L.: É! E naquela época não tinha ninguém. O que acontecia é que eu dava História da Educação para as moças e com a absoluta ausência de mulheres nos textos oficiais, nos livros. O que eu sempre digo é que a minha motivação de fazer o meu doutorado nessa

\footnotetext{
${ }^{1}$ O currículo Lattes da professora Guacira está disponível em http://lattes.cnpq.br/1021533829770484
} 
área, foi aí que começou, foi uma demanda muito prática, de sala de aula, porque as gurias perguntavam: onde é que estão as mulheres na história da educação? E aí eu buscava respostas que eram sempre, como eu costumo comentar, nota de rodapé, era assim, um pequeno detalhe. Então quando eu decidi fazer doutorado e me candidatar lá na seleção da UNICAMP, eu tinha que apresentar um anteprojeto de tese e eu propus algo pretencioso, como quase todos doutorandos fazem: eu queria fazer a história da educação da mulher no Rio Grande do Sul. Apenas! Aquela pretensão imensa que tu tens antes de efetivamente começar a pesquisar. Então, comecei, busquei a UNICAMP porque no meu ponto de vista era uma universidade muito inovadora e, comparada com a UFRGS da época, ela era muito revolucionária e o meu curso de História foi feito todo no período do golpe, quer dizer, no período da ditadura no Brasil, então realmente eu tinha uma certa carência de leituras de uma história mais crítica, que eu tive na UNICAMP. E isso com um orientador que, embora não tivesse nenhuma proximidade com os estudos de gênero (aliás, a palavra gênero nem eu mesma usava), aceitou essa proposta, que tinha como tema a história da educação da mulher no RS. Ao desenvolver o doutorado, primeiro eu me dei conta da enormidade do projeto, que seria uma coisa que eu não poderia fazer naquele curto espaço de tempo e então reduzi o foco para estudar a história da mulher em uma instituição específica, que foi o Instituto da Educação, a escola onde eu havia estudado, e fui muito bem acolhida pelo meu orientador. Na verdade, o que eu sempre fiz foi a história da mulher e é assim que está na tese, trabalhando com a categoria de contradição, a categoria da perspectiva marxista em História e com a ideia... Bom, eu não sei se faz sentido eu desenvolver como era o núcleo da tese mas, enfim, era isso, a categoria de contradição... É importante dizer isso, pois a escola que preparava as mulheres para serem boas professoras, bastante obedientes, dóceis, boas mães, essa mesma escola também dava instrumentos para elas se apoderarem de elementos para criticarem, para pensarem, para escreverem. Então a ideia é de que a própria educação dá os elementos para subverter aquela educação. Foi isso. Quando eu volto a Porto Alegre, volto para a minha área de História da Educação e como nosso Programa de Pós-Graduação da UFRGS naquela época já tinha uma grade curricular bem aberta, em que nós podíamos propor a disciplina que queríamos oferecer, eu comecei a propor História da Educação da Mulher, depois fazer seminário sobre a Educação da Mulher, até que eu entro em contato com a categoria gênero, através do texto da Joan Scott e aí começo a fazer trabalhos com gênero e tal. Então esse é o começo da história. 
F.S.: Eu queria fazer uma outra pergunta sobre isso. A primeira vez que eu te vi foi quando tu foste banca de uma pessoa que, obviamente, tu não vais mais lembrar depois de tantas bancas, uma orientanda do nosso colega que já faleceu aqui, o Nilton Bueno Fischer, e que fez uma pesquisa sobre o movimento sindical e entrevistou uma série de mulheres. Eu fui assistir, ela foi minha colega na História e eu me lembro que tu avaliaste a tese e sugeriste, tendo em vista que ela tinha entrevistado muito mais mulheres do que homens, que ela poderia ter trabalhado com a categoria de gênero e recomendaste o texto. Eu me lembro muito bem, foi a primeira vez que eu me lembro de ti, eu nem estava na faculdade ainda. E sobre isso, eu queria perguntar como tu foste fazendo este caminho, e não necessariamente outras colegas, pois a área de História da Educação é uma tradicional área dentro dos cursos de Pedagogia e também nas pósgraduações, ela é muito mais forte na Educação do que na História, mesmo. Eu queria que tu comentaste um pouco sobre a tua relação lateral com colegas, com outras instituições, quem mais tu percebeste, digamos, percorrendo essa trajetória.

G.L.: Pode-se dizer que essa trajetória vai ser uma continuidade do que eu já vinha dizendo antes, porque quando eu voltei para Porto Alegre com o doutorado concluído, eu já tinha ido a, talvez, uma reunião da ANPED. Aí eu passo a trabalhar no programa de Pós-Graduação de Educação e a ANPED era e é um espaço muito importante para debate e encontro acadêmico de mais alto nível, digamos assim. Então, na verdade, acho que posso dizer que eu, junto com mais umas colegas, passo a ser fundadora, acho que não é bem certa esta palavra, do GT de História da Educação da ANPED.

F.S.: É o GT 2 eu acho..

G.L.: É! Não sou fundadora, mas sou do núcleo desde o início do GT. E ali eu fiz uma apresentação, um trabalho para apresentar, naquela época a estrutura não era bem como é agora, que era uma síntese da minha tese. Acho que eu posso falar isso, que aquele foi o primeiro trabalho com essa ideia de gênero, de feminino dentro do GT de história, mas que tinha muitas outras colegas dispostas a trabalhar com isso e que já trabalhavam, também, mas não tinham apresentado trabalho ali. Então eu comecei a fazer ligações com pessoas como Eliane Marta, da UFMG, a Clarice Nunes, que não vou saber o nome da escola mas, era do Rio de Janeiro. Bom, então começou a se formar, dentro do GT de História da Educação, um grupo que trabalhava com mulher, 
com feminino, não sei te dizer, talvez seja até muito, concomitantemente, paralelo a isso, aqui no nosso PPG eu vinha fazendo seminários e tinha uma boa receptividade, tinha muita gente a fim de discutir estas questões. De novo, fundamentalmente mulheres, mas aparecia um que outro homem e eu sempre conto essa história quando me perguntam, sobre um rapaz que fez um dos primeiros seminários e eu fiz aquela pergunta: então, o que te trouxe até aqui? E ele queria conhecer melhor as mulheres para poder se dar melhor com elas, era uma motivação, assim, completamente não acadêmica. Mas eu comecei a trabalhar naquele espaço e aos poucos começaram a surgir algumas estudantes que estavam bastante interessadas e nós pensamos em criar um grupo e é então que a gente resolve criar o GEERGE. Naquele momento inicial eu posso dizer que a Rosângela Soares, que era minha orientanda de mestrado, a Dagmar Meyer, que naquela época quando a gente compôs o GEERGE eu acho que ainda não estava fazendo doutorado, eu não sei exatamente, mas Dagmar, Rosângela, eu e mais algumas pessoas nos reunimos e a ideia era formar um grupo de estudos de educação e relações de gênero e eu acentuo isso: que ele era um grupo de estudos. Naquele grupo inicial, também o Alex Branco Fraga fazia parte, eu não vou saber falar o nome de todas as pessoas, mas essas três pessoas eram realmente muito próximas e continuaram, a gente estudava, a gente pegava autoras e teorias que para nós eram difíceis e em grupo estudava e era assim. Eu gosto sempre de falar isso, porque não havia nenhum pudor de eu dizer alguma coisa que eu não sei, que eu não entendi, realmente era um grupo de estudos, dentro do GEERGE no início não tinha aquela ideia de que eu tinha que ir no GEERGE ensinar, o GEERGE era para nós estudarmos e nós tivemos alguns outros espaços, também, bastante significativos, em algumas das greves da UFRGS a gente se reunia com o pessoal do IFCH, com muita gente. Mas o que eu quero chamar atenção é para o seguinte: em um período da greve nós reunimos o GEERGE e o GEIRCH, que era o grupo de estudos interdisciplinares do IFCH para estudar, naquela ocasião, por exemplo, Bourdieu, discutindo a Dominação Masculina, mas lemos Bourdieu em francês, quer dizer, a gente fazia assim, uma coisa conjunta. Realmente eu valorizo muito essa época de formação, teoria, que foi importante para os estudantes, mas foi importante para nós, professores também, para mim foi. Eu reconheço o GEERGE como um espaço onde eu estudei, também, muito significativo.

F.S.: Tu adiantaste, agora, uma pergunta que estava logo aqui. Na UFRGS, hoje em dia, é possível identificar diversos grupos que lidam com gênero e sexualidade, tu conheces 
todos? É o da Educação Física, tem alguma coisa na Ciência Política, tem sobre Antropologia do Corpo e da Saúde, tem o da Fabíola Rhoden, tem o nosso, tem lá na área de literatura, algumas pessoas ao redor da Rita Schmidt e depois tem grupo ali nas Ciências Básicas da Saúde, que é uma outra orientação, digamos, assim das ciências humanas. Então, eu gostaria de saber como foi a relação do GEERGE com os outros grupos? Eu me recordo que uma vez, a Pró-Reitoria promoveu uma conversa de grupo sobre gênero. Eu acho que tu não estavas, mas eu fui com a Rosângela e nós falamos sobre o GEERGE, estava essa gente toda lá.

G.L.: $\mathrm{Na}$ verdade, eu acho importante dizer, não sei como vão ser colocadas as questões, mas gostaria de dizer um pouco sobre como o GEERGE funcionou durante esse tempo dentro da faculdade e essa articulação externa. Muitas vezes as pessoas contam as histórias desses grupos com certa dose de vitimização, algo que não foi o nosso caso, eu não registraria como se nós tivéssemos tido qualquer tipo de hostilidade ou menosprezo dentro da faculdade, não. E acho que isso se deve em parte à seriedade com que a gente iniciou o Grupo e a seriedade a qual a gente imprimiu ao Grupo desde o início. A princípio, dentro do Programa de Pós-Graduação, ele existia como um grupo onde as mulheres ficam lá discutindo sobre as coisas delas, não tínhamos uma articulação muito grande, mas também não tínhamos hostilidade. Mas, acontece que isso não é uma história isolada, é uma história que está acontecendo no país todo ao mesmo tempo, grupos de estudos de mulheres, grupos de gênero estavam acontecendo no país como um todo. Então, houve logo de início essa articulação com o pessoal do IFCH, que era mediada através da ANPED com outras pesquisadoras interessadas em gênero, não necessariamente com grupos, mas com pesquisadoras e, com isso, a gente tinha um diálogo mais ou menos nacional. Eu lembro, eu acho que o ano era 1990, não tenho assim absolutamente certeza, que eu fui em um evento em São Paulo que reunia os grupos de Estudos de Gênero naquela ocasião existentes no país, era uma coisa da USP e eu fui representando o GEERGE e o Grupo do IFCH, fui representando os dois grupos e então a gente já se articulou com outras estudiosas, pessoas do Brasil todo que estudavam gênero. Então, assim, de certa forma havia não uma coisa institucionalizada, mas mundialmente as pesquisadoras iam a alguns grupos por circunstâncias de participações em bancas, que eram os momentos que a gente tinha para dialogar. Então, realmente a princípio eu era sozinha, quer dizer, eu era a única com doutorado, mas depois, quando a Dagmar fez doutorado também, nós já éramos duas e éramos 
chamadas para as bancas fora do estado. Com isso, sempre que havia algum tema, alguma tese, alguma dissertação relacionada com estas questões, a gente tinha a chance de dialogar com colegas ou com grupos de outras universidades que estavam trabalhando esses temas.

F.S.: Eu fiz a pergunta porque eu acho que quando a gente olha a idade dos outros grupos, percebemos que eles se criaram mais ou menos por ali. No âmbito aqui dentro do Rio Grande do Sul, que tem essa concentração enorme de Programas de PósGraduação em Educação, tem 8 ou 9 em Porto Alegre, tu lembras de conexões ou coisas assim com outras instituições?

G.L.: Assim, o que eu posso te dizer é que essas conexões são muito mais acadêmicas, pessoais, do que propriamente institucionais. Mas eu lembro, por exemplo, de contatos com Pelotas, com o pessoal de Rio Grande, também, mas, é mais recente, mas Pelotas mais antigo. É o que eu me lembro de contatos e, também, porque a esse núcleo inicial do GEERGE, depois se acrescentaram a ele outras pessoas, a Jane Felipe vem um pouco depois e, por exemplo, a Jane é uma pessoa que tem contato, relações mais próximas com Pelotas, aí tem a ver com o que cada uma das pessoas fazem, assim, com esse trabalho de contatos.

F.S.: Sim, a Jane fez concurso em Pelotas, começou lá, depois fez o concurso da UFRGS e veio para cá. Nessa linha que a gente está indo, um outro bloco que eu considero importante abordar é que as coisas vão se criando e elas têm uma relação com o movimento feminista [...] porque isso não é só sobre a conexão com outros grupos de pesquisa, mas também com outros movimentos e lugares como, por exemplo, o Seminário Fazendo Gênero. Então, queria que tu conversasses um pouco sobre o movimento feminista, no geral.

G.L.: $\mathrm{Eu}$ acho que, novamente coloco, eu fortaleci esses estudos a partir da tese de doutorado. Até a tese de doutorado eu ainda estava trabalhando com o tema mulher, depois, então, eu entro em contato com o texto da Joan Scott "Gênero: uma categoria útil de análise histórica", trazido aqui em Porto Alegre pela Eliane Marta e me disponho a traduzir esse texto. E essa tradução do texto considero que foi uma coisa importante, porque nós fizemos um número especial da revista Educação \& Realidade, em que esse 
texto teve muito destaque e ele foi publicado duas vezes na revista, mas aqui eu falo da primeira, pois na primeira ele era um texto que muita gente usava no Brasil, muita gente falava, mas como o original dele era em inglês, na medida que ele aparece em português, ele se populariza mais. Então isso foi um dado importante mas, depois por condições muito pessoais, eu comecei a viajar um pouco mais e é aí que eu entro em contato com o que se faz fora do Brasil, o meu contato, assim, muito concreto, muito pessoal, foi em Nova York, visitando livrarias e principalmente muito próxima da Universidade de Columbia, eu percebi que o meu impacto é muito físico quando eu entro nas livrarias, vejo o quanto existe de publicações sobre mulher e sobre gênero e começo a trazer o que posso disso, a me apropriar o máximo possível dessas coisas. Então, eu estou contando uma trajetória que é muito pessoal, mas ela é uma trajetória que tem toda conexão com a trajetória que está se passando no conjunto, ou seja, o GEERGE não brota como uma coisa autônoma e autóctone daqui, há uma efervescência que é internacional e que nacionalmente adquiriu muita importância, principalmente na pós abertura, quando começa a voltar para o Brasil uma porção de estudiosas que tinham ficado exiladas na França, tinham estado em outros países, que vêm com essas informações e com alguma coisa que dá um elemento mais teórico de reflexão a uma militância, porque a militância feminista já existia, mas a militância feminista no Brasil tinha determinadas características que tinham bastante a ver com as condições históricas e sociais especificas do Brasil. A militância feminista aqui, em um dado momento, é muito contra as questões da ditadura, mas acontece que algumas questões marcadamente feministas internacionais passam a ser incorporadas aqui, também. Tudo isso para dizer que há um clima geral de efervescência para essas questões e que quando nós vamos criar o nosso grupo, ele nasce, também, em um contexto em que outros grupos também estão nascendo e dialogando com esses grupos, eu acho que é por aí.

F.S.: Eu vou fazer esta pergunta porque eu queria que a cena ficasse registrada para ir na entrevista, embora tu já tenhas falado. Desde que eu fui na ANPED, eu acabei virando coordenador do GT, eu andei em outros grupos e esse elemento de uma certa mistura de heroicidade e vitimismo nas trajetórias, ele aparece. E a cena que eu queria te lembrar, que provocou gargalhadas, tu vais lembrar dela, é que tu foste entrevistada ali por mim, na sala 102 da Faculdade de Educação da UFRGS, em uma noite que estava absurdamente lotada, em um daqueles eventos que a FACED fez. Tu já estavas 
aposentada e a primeira pessoa que se voluntariou a perguntar, embora diversas pessoas tenham levantado o braço, foi um menino, claramente gay, e ele fez uma pergunta que foi assim: Professora Guacira, eи queria muito que a senhora falasse, pois eu fico pensando no quanto hoje em dia, com todas essas brigas de gênero, o que a gente sofre, o movimento gay... Fez toda uma falação e terminou dizendo assim: A senhora, quando criou o Grupo, deve ter passado muito trabalho. E tu respondeste: Olha, quando eu criei, ninguém ligou! Resposta que provocou uma gargalhada geral no auditório e tu deste uma explicação um pouco nessa linha que tu falaste a pouco, das reações dos colegas. Talvez tu pudesses falar um pouco mais sobre a quem aquilo chamou atenção ou se foi visto como um tema menor, porque tu também estás narrando uma trajetória em que a questão do gênero se coloca no nosso Programa quando o referencial marxista, tanto na História como na Educação, é muito forte, então talvez o fato de não se incomodar com o tema é porque ele era tão menor que o paradigma dominante, que... sei lá... uma coisa assim.

G.L.: Eu diria que na UNICAMP, no âmbito onde eu fiz o doutorado, claramente diziam que eu estava discutindo uma contradição secundária da sociedade, pois a contradição primária é a contradição de classe. Mesmo na UNICAMP onde eu fiz o doutorado - eu defendi em 1986 e ali também tinha espaço para discutir isso - era um tema, mas não era a luta principal. Isso é importante dizer, e nem eu acho que tenha que ser a luta principal, só que tinha uma hierarquização de lutas e essa não era a principal. Quando o tema foi trazido para a UFRGS, na nossa faculdade, o que eu digo é que considero que tenha a ver com a minha volta, porque fui eu que comecei a disciplina na pós-graduação. Então, considero que foi apresentado de uma maneira séria e que a coisa foi acolhida pela coordenação do curso. Ela não foi engrandecida, mas ela também não foi hostilizada, então, sem querer fazer um auto-elogio, mas eu levo a sério o que eu faço, então acho que eu passei uma ideia de que estávamos fazendo uma coisa séria, estava bem distinto de uma militância, nós fazíamos um trabalho de aprofundamento teórico e, com isso, nós fomos granjeando respeito e mais tarde, muito mais tarde, admiração. Porque a princípio é assim, é uma ideia, mas pode trabalhar aquilo lá e nós aqui, então eu não tenho história de vitimização para contar, entende? De modo algum, não houve perseguição, só não houve, assim, uma grande importância, não foi dada, agora eu penso que depois de algum tempo de atuação do GEERGE e das disciplinas entre o pós, isso começa a ser respeitado, porque o GEERGE começa a ganhar um 
respeito mais nacional, eu acho que a gente ganha respeito na ANPED, então esse respeito nacional reverbera aqui. Eu não sei nem de onde vem, qual a origem de um ou de outro, mas eles se complementam, tanto que chega um dado momento que na ANPED um grupo me procurou com a ideia de fazer, acho que se deve contar isso, com a ideia de fazer um GT que trabalhasse exclusivamente gênero, porque curiosamente como havia dentro do GT de História da Educação várias pesquisadoras trabalhando com gênero, era curioso, porque alguém apresentava o trabalho pra ANPED discutindo, digamos, o ensino de matemática sobre a perspectiva de gênero e não sabiam mais em que GT iam colocar. Tudo que falava em gênero ia para a história, só que as vezes o trabalho não tinha nada a ver com história, então nós discutimos muito a ideia, nós ficávamos sempre em dúvida sobre o que seria melhor, se a questão de gênero deveria atravessar todos os GT's de forma que fosse efetivamente uma categoria, uma dimensão importante a ser pensada fosse qual fosse o tema: formação de professores, política educacional, educação de jovens e adultos, currículo, qualquer assunto que tivesse um viés ou uma perspectiva de gênero. Muitas de nós, e eu estava incluída aí em determinado momento, pensávamos assim, que era importante que o gênero contaminasse todos os GT's. Porém, a gente descobre, também, que se aprofunda cada vez mais a teorização específica de gênero e de sexualidade, que começa a vir logo a seguir. Ela, então, precisava de um espaço em que fosse discutida com profundidade, como o tema central, não se podia discutir, por exemplo, perspectivas historiográficas e também discutir teorização sobre sexualidade, nós começamos a achar que precisava de um espaço em que gênero e sexualidade fossem o motivo central dos questionamentos. E aí um grupo de pessoas me procurou, pela trajetória que eu já tinha, porque eu já tinha sido coordenadora do GT de História e depois vice-coordenadora do mesmo GT por muito tempo, eu era uma pessoa que tinha uma história dentro da ANPED, para fundar o GT de gênero, a gente fundou e aí, sim, houveram algumas discordâncias importantes. Nós levamos para uma assembleia geral da ANPED e tivemos uma discussão significativa, tivemos que ficar até tarde da madrugada votando aquilo e convencendo, colhemos assinaturas e tal para convencer os colegas que se justificava mais um GT. E, bom, depois foi aceito e tomou o rumo que tomou o GT 23, né.

F.S.: É, só tem um GT, depois, nessa numeração, pois são 24 GT’s, então só teve a criação de mais um, foi junto com o de Educação Ambiental, eu acho que se criaram 2 ou 3. 
G.L.: É, um argumento que não deixa de ser válido, também, é de que não podia se multiplicar tanto os GT's indefinidamente e tal. Todos os argumentos eram válidos, mas nós estávamos achando que merecia ter um espaço para discutir essas questões. E aí, então, eu ajudei a criar e fui a primeira coordenadora desse GT 23.

F.S.: A outra questão, aqui, é que eu tenho uma aluna na disciplina que estou ministrando com um colega da administração que pretende se credenciar no nosso Programa e trabalha com formação para o mercado e gênero. Lá tem uma menina que é da biblioteconomia, ela é servidora da UFRGS, está no doutorado e o trabalho dela é uma coisa bibliométrica, para usar uma expressão da área e ela, então, levanta as bibliografias que estão citadas em 400 mil lugares, ela já me explicou e eu já esqueci. Então, recentemente ela sentou comigo e disse: Eu queria te dizer uma coisa, Fernando, eu vou concluir o levantamento e são duas as autoras, Scott e Louro, com uma base de dados enorme, sendo que no caso da Joan Scott as citações são predominantemente de um texto [que é esse que tu referes] e no caso da Guacira, as citações são disseminadas em diversos textos. Então, tu apareces mais vezes, assim que ela disse isso, eu me dei conta, eu tenho ido a muitas bancas, não há trabalho de gênero que não tenha a Scott, alguns ainda têm usos e abusos de gênero, ou seja, as outras coisas que ela escreveu, mas as pessoas ficaram nesse primeiro. Agora, dificilmente tem um único texto teu, claro que eu sei que tem aquela coisa da língua, tu publicaste tudo em português. Mas, assim, tudo isso é para fazer a pergunta. Quando a pessoa entra num campo que está se estabelecendo, ela também é responsável por trazer as bibliografias, no teu caso, tu estás muito associada com o pensamento da Butler e o pensamento da Scott e eu queria que tu comentasses um pouco sobre isso. Assim como o Tomaz Tadeu da Silva, quando eu formulei essa pergunta, eu fiquei pensando, o Tomaz, por exemplo, também é muito citado, eu vou lá olhar por curiosidade. O Tomaz está citado indiretamente em muitos textos, porque eu sei que foi ele que traduziu, ou aquela coisa sobre pedagogias culturais, quase tudo está em livros que ele organizou e ele próprio traduziu, ele trouxe muitos autores, então eu digo que, na verdade, existem duas citações do Tomaz em algumas teses dele propriamente e de outras coisas que não teriam chegado ao Brasil naquela época se ele não tivesse traduzido, mas, toda essa falação é para fazer uma pergunta que é mais ou menos por aí... 
Guacira Louro: Não, acho que isso me permite falar sobre uma coisa que eu gosto. Eu me sinto toda vida profundamente professora, mais do que tudo, eu sempre me apresento como uma estudiosa e uma professora. Então, quando eu começo a dedicar aos estudos nessa área, eu entro em contato com muita literatura e algumas bastante difíceis para mim, também. Judith Butler eu acho até hoje uma autora extremamente difícil e eu me atribuía uma missão, missão é uma palavra meio dramática, mas a tarefa de trazer isso para a sala de aula, então por isso que eu digo que me sinto sempre professora, porque eu sempre valorizei ser compreendida, eu sempre valorizei que as pessoas comuniquem de forma com que os outros entendam o que está sendo comunicado. Por isso, penso que temos que estudar bastante para poder simplificar, ninguém pode simplificar sabendo mais ou menos, tu tens que estudar para poder dizer de uma forma mais simples. É claro que eu não só fazia isso em termos de dar aulas, mas, também, escrevi bastante, escrevia, gosto muito de escrever. Então, acho que essa questão de ser bastante citada, tem a ver com isso, é a mesma língua, eu acho que o meu texto é um texto mais acessível e eu gosto disso, não considero indicador de que alguém é muito magnífico teoricamente porque escreve difícil. Pode ser necessário, mas eu não considero. Eu penso que podemos e devemos tornar a leitura acessível e, mesmo afastada da faculdade, eu continuei escrevendo. A pretensão, nesse último livro que eu escrevi, foi e acho que eu consegui, atingir um público que vai além da universidade, porque eu mexi com cinema, com literatura. A ideia é de que não precise ser alfabetizado na teoria, não precise ser iniciado na teoria para poder ler alguma coisa e ficar tocado pelo micróbio das questões de gênero e sexualidade. A minha ideia é essa, eu valorizo que a gente comunique para que as pessoas compreendam. Acredito que isso tenha a ver com o fato de eu ter escrito bastante e daí as pessoas leram...

F.S.: Era isso, então, também tem a coisa da tradução. Eu sei que já te perguntaram isso outras vezes, mas é meio incontornável essa pergunta. É que o teu nome ficou associado ao da Butler no Brasil e com essa transformação dela como um fenômeno cultural, político e o acadêmico. Tu já me contastes algumas vezes as histórias de como tu encontrastes os livros e tudo, mas eu quero te perguntar como é que tu enxergas isso e como é tu vês toda a repercussão que teve, inclusive gente queimando ela em praça pública, até uma bruxa lá em São Paulo e tudo isso que eu sei que assististes, porque saíste do seminário em São Paulo e depois foste olhar o que estava acontecendo lá fora. 
G.L.: Na verdade, eu acho que vale a pena contar um pouco, fazer a caminhada de dizer que a gente acentuou bastante os estudos de mulher, os estudos sobre gênero e em um determinado momento as questões de sexualidade se põem como importantes. Isso eu já contei várias vezes, vale repetir aqui que isso se dá muito pela demanda dos professores e das professoras que estão nas escolas com as crianças e adolescentes e que demandam ao GEERGE respostas de como lidar com a sexualidade, não é propriamente gênero, é sexualidade, a grande preocupação é com a homossexualidade, era a preocupação primeira, vamos dizer assim. Então, isso vai fazer primeiro um movimento mais pessoal, mas depois um movimento que envolve muitos colegas do grupo do GEERGE, de estudar sexualidade e ao começar a estudar alguns autores gays, lésbicas, é nesta caminhada que eu me deparo com a Judith Butler e que me aparece pela primeira vez o queer, a palavra. Eu já contei isso, uma coisa meio anedótica, até, mas é real. Eu estava em uma livraria, em Nova York, olhando um livro que me chama atenção, que é Gender Trouble e a capa do livro me chamou a atenção, eu resolvi comprar e tentei fazer o ensaio de traduzir pra mim mesma, que achei muito difícil, mas muito instigante. Eu considero a Judith Butler uma grande pensadora! Uma grande pensadora! Acho que ela é muito difícil de ler, considero a comunicação dela difícil, mas ela é provocadora, foi provocativa para mim e me dispus a estudar e acho que talvez, de novo, porque eu estou um pouco associada a isso, foi um artigo significativo que foi o da revista Estudos Feministas, que se chama Uma política pós identitária para educação ${ }^{2}$. É um artigo que, no fundo, trata de como foi se dando esse processo de pensamento e de militância no Brasil. Bom, então é isso, eu valorizo muito o trabalho dela, o que eu conheço um pouco melhor é o Gender Trouble e o Bodies that matter, mas li outras coisas dela e depois me meti com muita dificuldade a traduzir um livro, que é uma espécie de introdução ao trabalho dela, que é o livro da Sarah Salih, intitulado Judith Butler, publicado pela Autêntica. Tive muita ajuda do Tomaz Tadeu, também, nessa tradução, porque realmente traduzir é uma habilidade difícil, uma coisa é traduzir para o teu próprio consumo e outra coisa é traduzir para publicar. Então é isso, obviamente eu acho que essas coisas do pensamento não se dão deslocadas dos movimentos sociais, das militâncias, dos movimentos políticos que estão acontecendo ao mesmo tempo e aí uma série de grupos, tipo ONG's, tipo aqui em Porto Alegre o Nuances, o Somos, que fizeram muitas ligações com o GEERGE, acho que isso

\footnotetext{
${ }^{2}$ Artigo disponível em http://www.scielo.br/pdf/ref/v9n2/8639.pdf
} 
também é algo muito significativo de aparecer numa trajetória. Quer dizer, nós tivemos articulações, mesmo, não era um negócio de um lado para o outro, era um negócio dos dois lados, tu, eu, demos aulas em eventos promovidos pela Nuances, por outro lado muitos dos militantes dos movimentos participaram de coisas da pós-graduação, então, a gente se misturou em várias situações e aí toda a ideia queer começa a adquirir uma maior visibilidade de uma maneira que eu acho mais simples, mas é a ideia de chamar de queer tudo que não seja heterossexual. Então, todos os sujeitos, todos os grupos, todas as práticas que não sejam heterossexuais, as vezes se auto-denominam queer e, por outro lado, em uma forma mais radical, que significaria mais pensar queer, que é a ideia do pensar supondo um constante questionamento, pensar contra corrente, pensar a ambiguidade, pensar o trânsito, que é uma coisa bem mais complexa. E eu procurei fazer um pouco de articulação entre o pensamento queer e a educação, dois pontos bem diferentes e até certo ponto contraditórios, porque um prega desobediência e o outro prega obediência, regração, normalização, então tudo isso foi esse caldo cultural. E a figura da Butler é um nome especial, eu acredito que talvez nem mesmo ela imaginava que poderia se tornar a musa, aliás, a expressão que eles usam é The Queer Queen (a rainha do queer), porque na internet a gente lê uma coisa sobre ela contando que alguém, em um jantar, pergunta para ela sobre o queer e ela pergunta: o que é isto? Ela nem mesmo se reconhecia, mas depois ela se vê envolvida e, efetivamente, ela é um nome fundamental para o movimento. E acho que aqui no Brasil, por circunstâncias bem particulares, históricas, sociais e políticas acabaram colocando na pessoa dela uma coisa muito complicada, demonizaram a figura dela, alguns grupos demonizaram, quer dizer, personificaram. Eu acho que ela nem corresponde a isso, ela é uma pessoa extremamente discreta, intelectual, eu suponho que até ela recusasse essa personificação que aqui assumiu.

F.S.: Eu tenho só mais duas perguntas, uma eu penso que tu podes recusar em responder, que é meio inevitável perguntar, mas é que já pegou o período que tu estás mais afastada. As questões de gênero e sexualidade tomaram ar de pânico moral na sociedade, isso já vinha acontecendo, mas agora estão ficando numa relação da ordem do apavorante mesmo, eu não vou negar... Mas, a pergunta é no sentido de te pedir para comentar sobre a centralidade que as questões de gênero e sexualidade tomaram, o quanto se associaram com coisas relativas ao pânico moral e foram parar na boca, por exemplo, de presidentes da república e em outros lugares. Além disso, hoje em dia, em 
vários eventos da área da Educação, a palestra de gênero é a da abertura do evento e eu considero isso uma coisa fora do comum, como na História eu também vejo isso, a palestra de abertura dos grandes eventos de História era sempre outra, era historiografia, era teoria, era da própria coisa da história do Brasil, de como chegou lá. Então, se tu quisesse comentar alguma coisa...

G.L.: Bom, alguma coisa eu vivi pessoalmente, por exemplo, eu fiz uma palestra de abertura de um seminário Luso Brasileiro de Estudos em Educação e como é algo extraordinário falar em gênero, alguns colegas de circulação internacional me perguntavam coisas do tipo: mas o que é isso que vocês estão discutindo? Com desconhecimento. Agora não está mais assim, mas o que eu observo a gente pode ler de várias formas e uma das formas de ver é que esses estudos, essa ação, não os estudos desses grupos teóricos e de militância, foi de tamanha importância que eles se tornaram visíveis e ameaçadores, então realmente essa preocupação, esse pânico moral tem a ver com a eficiência, eu acho, da ação e do estudo desses grupos. Se em alguns momentos houve excessos e coisas feitas superficialmente? Eu tenho certeza que sim, assim como em qualquer área teve. Criar coisas que são superficiais, isso existe dentro dessa área, então acho que os estudos foram bastante significativos, eles assustaram e nós estamos vivendo, de alguns anos para cá, uma onda forte conservadora de grupos que tomaram esse ponto como um foco importante, acho que paralelamente a isso tem um dado que talvez a gente deva, também, considerar, estudar, se interessar pelas questões de direitos humanos ou pelas questões dos direitos das minorias e, no caso, especificamente, de gênero e sexualidade, é um interesse, é uma posição que tu podes assumir independentemente do partido político que tu tenhas e acontece que isso ficou muito partidarizado, ficou sendo muito ligado a um partido político, que foi o partido dos trabalhadores. Então ficou como uma forma de atacar o PT e de derrubar as bandeiras que muitos de seus militantes levavam, claro que essas bandeiras tiveram mais visibilidade no período petista, mas nem todos os militantes, nem todos os estudiosos têm essa posição política, então eu penso que se confunde, hoje, os estudos de gênero e sexualidade com determinadas posições políticas e partidárias e esse borramento de fronteiras, como se fosse a mesma coisa, tem complicado. Esses tantos caras que falam em ideologia de gênero, que atacam e dizem horrores do que se pudesse estar fazendo nas escolas, têm a ver muito, também, com um ataque a um determinado partido, então, claro, foi forjada essa expressão ideologia de gênero e agora está na boca de todo mundo. 
F.S.: A última pergunta era na linha spoiller, as entrevistas terminam com isso, se tu tens algum livro pensado, se tens alguma coisa, algum tema que na costura do gênero tu consideres interessante ou em sexualidade, se tens alguma área emergindo nessa superfície toda, o que tu achas? A mim, surpreendeu no dia 8 de março, uns dias antes, quando tu colocastes o livro da Virgínia Woolf ${ }^{3}$, quer dizer, tu mandastes para nós, pois tu não tens Facebook. Eu até publiquei no meu Facebook com a imagem, foi só entrar no Google imagens e eu vi, estava lá a imagem do livro e aquilo alimentou, nos comentários da minha postagem, a ideia de que "a Guacira segue escrevendo". Então, assim, tudo desata em uma ansiedade.

G.L.: Eu continuo escrevendo, sim, das coisas que eu mais gostei que fiz nos últimos tempos foi o Flor de Açafrão ${ }^{4}$. Eu gosto particularmente desse livro porque consegui juntar uma coisa que sempre me atraiu, que é o cinema e a literatura para pensar gênero, pensar sexualidade de uma forma que fosse provocativa para qualquer pessoa, evidentemente para pessoas sensibilizadas para as questões sociais e tal, porque é uma leitura que não é banal, mas ela não é uma leitura de iniciados teóricos, isso eu gosto muito e talvez eu vá fazer um outro por aí. Eu agora estou coordenando, junto com duas colegas, uma coleção chamada eFe, com e minúsculo, f maiúsculo e e minúsculo, f de feminista. Da Autêntica, então nós estamos com o livro para sair e eu estou agora fazendo algumas revisões aqui, mas o livro está para sair em breve e o nome é Sister irmã Outsider, que é de uma escritora negra feminista e esse livro está no processo já de quase sair e eu devo ir a Belo Horizonte para discutir a continuidade dessa coleção. Então, na verdade, eu que comecei com o estudo das mulheres, entrei para gênero e muito de sexualidade, eu acho que estou quase que voltando para as questões feministas, é que as questões de sexualidade sempre me mobilizaram muito, mas eu estou voltando, porque o tema está em tudo que é lugar, não é só nacional, é internacional, então quando a gente descobre e, no meu caso não fui eu que fiz isso, foi o Tomaz Tadeu que fez isso, os textos da Virginia Woolf escritos nos anos 30 e que tem uma potencialidade incrível para pensar o momento atual, então eu continuo estudando e escrevendo, mas, assim, muito partindo dos meus desejos, muito partindo do que me empolga no momento.

\footnotetext{
${ }^{3}$ As mulheres devem chorar... ou se unir contra a guerra. Patriarcado e Militarismo. Virgínia Woolf (autoria), Tomaz Tadeu (Organização), Guacira Lopes Louro (Posfácio), Editora Autêntica, 2019.

${ }^{4}$ Flor de Açafrão: takes, cuts, close-ups. Guacira Lopes Louro. Editora Autêntica.
} 
Tiago $^{5}$ : Teve duas cenas da entrevista que eu gostaria de resgatar algo mais. A primeira é a leitura do Bourdieu em francês, porque eu acho que ali tem um jeito de estudar e produzir o conhecimento que é muito nosso, quando falo em nosso, é latino-americano, brasileiro, sei lá, é importante olhar para esse lugar da região do país e eu queria saber como foi, nessa trajetória, essa forma de produzir aqui, com o pé aqui, na greve, o Bourdieu em francês, mas vocês estão aqui em período de greve. Eu acho que isso é muito interessante, no momento em que está todo mundo meio antenado nas discussões mais decoloniais, pós-coloniais e aí ouvir que foi nesse contexto que se iniciou, eu acho que tem tudo a ver com a forma que se produz o conhecimento aqui. Eu queria ouvir um pouco sobre isso.

G.L.: Tem um ponto agora, na tua fala, bem no fim, que quase que parece marginal, mas que é importante de dizer. A UFRGS, a nossa universidade, fisicamente ela é muito dividida, porque nós, da Educação, atuamos no Campus do centro, depois tem o campus do Vale, então tu não imaginas o que de diálogo nós tínhamos, propriamente dito, na greve. Por incrível que pareça, eu e muitas outras pessoas - fui uma grande militante da UFRGS, da associação docente - nas greves, é um absurdo, mas, nós vivíamos mais a universidade, nós estávamos mais juntos, todas as áreas e por exemplo, a Educação ficar longe do IFCH é um problema. Onde está a História, onde está a política, onde está a Geografia, onde está, sei lá, a Antropologia, e a greve nos dava a chance. As aulas pararam e a ideia era ainda que tu não estivesses dando aula, nós queríamos demonstrar que nós estávamos produzindo, ou melhor, a greve não era parar por parar, nós estávamos fazendo um protesto, nós não estávamos dando as aulas, mas era o momento que nós tínhamos para produzir conhecimento, então a reunião era com professores, professores de lá do IFCH e daqui do GEERGE. E a gente realmente destrinchava um autor difícil, nós tínhamos no grupo a Cláudia Fonseca, que domina francês e que ajudava muitíssimo, então ali a gente estudava, me permite lembrar isso, muito importante, a conjuntura, a situação física da UFRGS, que muitas vezes não propicia esse diálogo intercampus e na situação de greve propiciava e a nós aproveitamos dessa forma. Foi muito bom, foi importante! Os dois grupos já existiam, eles estavam assim fazendo os seus processos e tal e esse texto de Bourdieu é um texto

\footnotetext{
5 Tiago Duque, professor do Bacharelado em Ciências Sociais da Universidade Federal de Mato Grosso do Sul (campus de Campo Grande), do Mestrado em Educação (campus do Pantanal - Corumbá) e do Mestrado em Antropologia Social da Faculdade de Ciências Humanas (FCH).
} 
muito criticado, existem algumas estudiosas feministas que execram o texto, que acham um horror. Bourdieu não tem nada de feminista, eu sei que ele não tem, mas acontece que era importante ler aquilo que o cara falava sobre a dominação masculina, sobre toda uma coisa que ele dizia que se inscrevia no corpo, a submissão feminina no corpo, então estudar aquilo, quer dizer, tu não pode estudar só aqueles autores que comungam perfeitamente com a tua ideia, tem que estar te provocando, também. Então foi isso, eu lembro desse estudo específico, talvez tenhamos feito outras coisas também.

Tiago: E uma segunda pergunta é sobre os encontros com os autores, com os livros nas bibliotecas, porque a gente vive um momento em que as livrarias estão se fechando, então a sensação é que nós temos um outro momento em que muitos grupos estão acessando, em uma era digital, as coisas pela internet. Mas no momento lá, 30 anos atrás, talvez um pouco mais, era físico e tinha esses desafios que tinham a ver com a tradução, com a língua, com o que já foi dito, mas o próprio trânsito, você teve que ir até os Estados Unidos, até a Europa, enfim, hoje não, ou pelo menos ainda que hajam limitações no acesso a internet, porque ainda é um país em que não é todo mundo que acessa igualmente, mas as coisas estão muito mais acessíveis, qual seriam esses desafios, então? Parece que o acesso, inclusive as questões de gênero, porque muita gente conheceu gênero a partir das coisas que você escreveu, então parece que o acesso não é tanto um desafio. Desafio, portanto, seria hoje o acesso para quem vai produzir, contribuir para essa área do conhecimento?

G.L.: É curioso, assim, eu acho que é real tudo isso que tu estás falando, anteriormente existia essa coisa do contato direto, físico, algumas pessoas tinham oportunidade, outras não, o meu caso foi em dado momento da minha vida de forma fortuita, que eu acho que eu aproveitei muito, mas agora realmente o acesso a informação é imediato e se universalizou muito, ainda que tu tenhas razão em dizer que nem todo mundo tem esse acesso, mas está muito, muito ampliado. Eu acho que o problema maior seria uma ajuda, uma ajuda como professores, uma ajuda acadêmica de um questionamento da formação que se prega, porque nós temos muitas bobagens escritas também, nós temos muitas inverdades, a palavra inverdade não é aqui a melhor para dizer, mas, assim, qualquer um pode publicar qualquer coisa. Então, por exemplo, assim falando em ideologia de gênero, tu podes encontrar argumentações, argumentações, argumentações e alguém muito bem intencionado vem e outro dia vieram até aqui me fazer uma 
entrevista e eu disse assim: vocês não usem a palavra ideologia de gênero, que eu não sei explicar por aí ... Eu acho que o problema principal agora é este, ajudar a ler criticamente que, aliás, tenha sido sempre essa a tarefa de professor, que é uma coisa de questionar, não é dizer assim, que eu tenho a verdade, mas eu tenho que ter alguns instrumentos para debater, provocar aquilo que as pessoas estão lendo, porque acesso tem aí aos montes, a Wikipédia, por exemplo, é feita por qualquer um, eu fui olhar esses dias o que diz respeito ao meu nome na Wikipédia e tem um algo que diz assim no final, que eu fiquei impressionada, diz assim: que eu acho normal a ideologia de gênero, uma coisa assim, sabe? Que eu acho normal... quer dizer, tem coisas absurdas e eu não sei nem mexer naquilo para consertar, mas eu acho que a ideia talvez seja de ajudar a ver criticamente as coisas. Eu, outro dia, fiz uma fala na aula, acho que da Dagmar e uma pessoa que estava ali presente, uma colega nossa, me questionou, porque quando eu comecei a contar a minha história, eu disse que como toda história, a gente começa dizendo era uma vez, então eu disse: era uma vez um tempo que não tinha computador, porque quando eu fiz o doutorado não tinha computador. Então eu comecei contando, falei da pesquisa e tal, e essa pessoa falou com muita nostalgia desse tempo em que então a gente tinha, realmente dominava, quer dizer a gente pensava que dominava, a gente tinha aqueles livros que estavam ali perto da gente, o que nós temos agora é um desafio o qual a gente tem que enfiar na cabeça que nós não sabemos tudo sobre nada, sobre nenhum assunto a gente sabe tudo. A ideia assim: eu domino, não domina coisa nenhuma, tu tens algumas informações e talvez seja essa a postura mais interessante a dizer se for diferente, o que mais se produziu, eu acho que ficar com essa ideia de incompletude é importante, eu penso que isso é importante, são coisas do pósestruturalismo, mais humildade no que tu estás afirmando, mais modéstia, vamos dizer assim, o que eu consegui foi isso, mas isso tem esse limite. Eu disse muita bobagem agora, aqui, mas em todo caso o importante, seria isso, que é ajudar a ler criticamente a tanta coisa que se tem acesso, porque a nós temos acesso a muita informação, mas, também, temos acesso a muita bobagem, qualquer um publica o que quer e nós sabemos, há blogs de tudo quanto é tipo.

F.S.: Muito opinionismo hoje em dia...

G.L.: Muito! Se essa opinião é apresentada como opinião, ok, mas acontece que algumas coisas são apresentadas como factuais, como resultantes, dizem fontes 
autorizadas, que raio de fontes autorizadas são essas? E o colesterol agora é não sei o que lá... Quer dizer, pegando como exemplo essa ideia da área da saúde, que não é a nossa, tu vês quanta coisa sendo dita sobre o que a gente pode, o que não pode e alguém te diz, com base em tal site, mas em um outro site diz uma outra coisa, então acho que é isso, é difícil, esse super acesso à informação trouxe com ele alguns problemas, mas é evidente que é bom a gente ter essa possibilidade.

\section{PRODUÇÃO DO GEERGE ${ }^{6}$}

Hoje a Universidade Federal do Rio Grande do Sul (UFRGS) está entre as dez instituições (dentre 236) com maior número de grupos e linhas de pesquisa sobre estudos de gênero no Brasil, segundo pesquisa realizada no Diretório de Grupos de Pesquisa (DPG) do Conselho Nacional de Desenvolvimento Científico e Tecnológico $(\mathrm{CNPq})$, cenário cujo protagonismo se deve, em grande parte, às pesquisas realizadas no GEERGE -Grupo de Estudos de Educação e Relações de Gênero. O GEERGE é um dos precursores nos estudos de gênero no Brasil. Foi criado na UFRGS pela pesquisadora Guacira Lopes Louro na década de 1990, quando a área era ainda incipiente no país.

Uma das grandes contribuições do GEERGE e da UFRGS para a área foi a publicação do texto de autoria de Joan Scott intitulado Gênero: uma categoria útil de análise histórica, traduzido pela pesquisadora Guacira Lopes Louro e publicado pela Revista Educação e Realidade, em 1990. Esse texto é um dos mais citados na área, conforme Soihet e Pedro $(2007)^{7}$, e a publicação de sua tradução figura como um marco para os estudos de gênero no Brasil, contribuindo para o crescimento da discussão sobre o tema no país.

O GEERGE tem destaque na produção sobre estudos de gênero na UFRGS. Segundo levantamento realizado no Lume, o Repositório Digital da universidade ${ }^{8}$, seus pesquisadores figuram entre os e as docentes com maior número de orientações de

\footnotetext{
${ }^{6}$ As informações apresentadas foram copiladas por Thaís Dias Medeiros - Mestranda do Programa de Pós-Graduação em Comunicação da Universidade Federal do Rio Grande do Sul - PPGCOM/UFRGS, Natascha Helena Franz Hoppen Mestra e doutoranda em Comunicação e Informação pela Universidade Federal do Rio Grande do Sul, bibliotecária documentalista da UFRGS, responsável pelos periódicos Em Questão e Intexto (PPGCOM/UFRGS) e Samile Andréa de Souza Vanz Doutorado em Comunicação e Informação pela UFRGS. Professora do Departamento de Ciências da Informação e do PPGCOM e PPGCIN da UFRGS, editora do periódico Em Questão.

${ }^{7}$ SOIHET, R.; PEDRO, J. M. A emergência da pesquisa da História das Mulheres e das Relações de Gênero. Revista Brasileira de História, São Paulo, v. 27, n. 54, p. 281-300, 2007.

${ }^{8}$ MEDEIROS, T. D. A produção científica sobre estudos de gênero no repositório digital da UFRGS: um estudo bibliométrico. Trabalho de Conclusão de Curso (Graduação em Biblioteconomia) - Faculdade de Biblioteconomia e Comunicação, Universidade Federal do Rio Grande do Sul, Porto Alegre, 2018.
} 
trabalhos de conclusão de curso, teses e dissertações sobre a temática na universidade. Com destaque para o curso de especialização em Educação, Sexualidade e Relações de Gênero, ofertado entre os anos de 2009 e 2011, ligado ao Programa de Pós-Graduação em Educação (PPGEDU/UFRGS) e ao GEERGE, que impulsionou a produção na área, sendo responsável por $60 \%$ dos TCCs de especialização sobre estudos de gênero Universidade, o que demonstra a importância e relevância do GEERGE para as pesquisas na área.

A produção sobre estudo de gêneros ligadas ao GEERGE e seus pesquisadores e pesquisadoras inclui uma extensa produção científica. Suas pesquisas ajudaram a impulsionar a produção sobre estudos de gênero na UFRGS e no Brasil. Guacira Lopes Louro, pioneira do GEERGE, é uma das maiores pesquisadoras da área no país. Sua produção é extensa - com mais de 100 trabalhos publicados, entre livros, capítulos de livros, artigos e anais de eventos - e possui grande impacto, tendo 3.792 citações, segundo Google Citation, ao seu livro Gênero, sexualidade e educação, de 1997. Assim como seus livros Um corpo estanho: ensaios sobre a sexualidade e teoria queer, de 2007, e O corpo educado: pedagogias da sexualidade, de 1999, com mais de 1.000 citações cada. Dados que evidenciam a importância do GEERGE e da UFRGS para os estudos de gênero no país. 